TURIZAM

Volume 20, Issue 1

33-47 (2016)

ORIGINAL

SCIENTIFIC PAPER

\title{
Tourism Market and the Movement of Visitors in "Tourism Strategic Area" in Indonesia
}

\author{
Syaiful Muazir*, Horng-Chang Hsieh** \\ Received: June 2015 | Accepted: March 2016
}

\begin{abstract}
Tourism industry has become one of important contributors of foreign exchange for Indonesia. In order to develop it, the central government has issued several policies, one of which is by assigning national tourism strategic areas across the country that also have a role to encourage other factors, such as economy, social-security, etc. This paper is an exploratory study on the existing tourism market in one of the national strategic areas, namely Sambas Regency in West Kalimantan, Indonesia. Besides, this study also observed the synchronization of this area with other attractions and other strategic areas (borderlands). After the tourism market was identified, the relation among the visitors' origins, the places they visited, and their next trips were explored to identify the dominant characters of the movement and places. This study used survey technique and network analysis. The findings conclude that the main tourism market in tourism strategic area was still dominated by domestic market with their specific characters. The visitors did not only visit the tourism attractions in Sambas, but also pass the border to go to the neighbouring country, either directly or through Sambas. This market niche can be "exploited" by Sambas regency by rearranging their attraction hierarchy, placing attractions around Sambas palace as the centre, and making the border either as an entrance or continued attractions.
\end{abstract}

Key words: Tourism, Market, Strategic, Movement, Indonesia

\section{Introduction and setting}

In Indonesia, tourism sector/industry is one of the largest contributors in terms of foreign exchange if associated with economic sector. In 2013, according to the Ministry of Tourism (2015), tourism sector ranked fourth in the category of foreign exchange earner after palm oil, coal, oil, and it produced 10,054.1 (in million USD). There is a tendency of increasing visiting rate (around 9-13\%) every year. The Ministry also published, that in 2014, tourism sector attracted around 9,435,411 visitors. However, the neighbouring country, Malaysia, successfully attracted 25.72 million visitors in 2013, to which Indonesia contributed the second largest number of tourists after Singapore. Moreover, with its 34 provinces, Indonesian tourism sector will face the challenges of rapid economic development resulting in the importance of sustainable development and equal distribution of people welfare. In details,

\footnotetext{
* Department of Architecture, Tanjungpura University, Pontianak, Indonesia, syaifulmuazir@teknik.untan.ac.id

** Department of Urban Planning, National Cheng Kung University, Tainan, Taiwan, hchsieh@mail.ncku.edu.tw
} 
the problems faced by Indonesian tourism sector summarized inside the Ministry of Tourism Strategic Plan 2010-2014 are (1) lacking readiness of the tourist destinations to compete in the global market, (2) limited availability and utilization of information communication technology (ICT), (3) low quality and quantity of human resources, (4) minimum investment in tourism sector, and (5) lack of public and private partnerships. Based on these conditions, the central government through Government Regulation has issued a National Tourism Development Master Plan (2010-2015) which is the "interpretation" of Tourism Law (2009). In this regulation, the government has developed a number of tourism development instruments; one of them is National Tourism Strategic Areas (NTSA), distributed in 88 locations around the country. NTSA are the areas that have the main function or tourism potentials which are assumed to have important influences on other aspects, such as economic, social, culture, natural resources, environment, and defence and security. Of 88 strategic areas in Indonesia, two are situated in West Kalimantan: (1) Sambas area and (2) Sentarum Lake area. Interestingly, when synchronized with the National Spatial Plan, these tourism strategic areas are adjacent with the National Strategic Activity Centre (NSAC) which is located in the border area in the same regency (Sambas and Kapuas Hulu regency). NSAC is an urban area that is designated to encourage the development in the State's border areas. In terms of the closeness of the tourism strategic areas and the "entrance" or border areas, a potential tourism attraction and an international market (Sarawak-Malaysia and Brunei Darussalam) are real opportunities.

This study is a case study conducted in a national tourism strategic area of Sambas regency in West Kalimantan province, Indonesia. Sambas regency is located in northern part of West Kalimantan with a total area of $6,395.70 \mathrm{sq} . \mathrm{km}$ or about $4.36 \%$ of the total area of West Kalimantan (146,807 sq. km). Sambas Regency is divided into 19 districts and 183 villages with the northern and eastern parts of it facing Sarawak-Malaysia. According to the national spatial plan, Sambas has designated as a regional activity center which serves the activities at the provincial or regional scale. Moreover, Paloh and Aruk are also designated as a national strategic activity centre which is defined as an urban area that serves to encourage the development in the border areas. Having been viewed from the closeness to the neighbouring countries (as the visitor source) and its tourism potential, Sambas is set as one of the strategic areas in tourism sector. The determination of Sambas as a tourism strategic area is based on its function and potential. A location is designated as a strategic area if it meets the criteria that the location/area has a significant impact on one or more aspects, such as economic, social, cultural development, the empowerment of natural resources, as well as defence and security matters.

This paper is a means to identify and recognise a tourism market in a tourism strategic area as well as its influence on the border area of the strategic district. This identification process is expected to provide inputs for tourism product development in tourism strategic area to meet the needs of the visitors. In addition, several indicators related to the visitors' expectation and motivation to go to other places were also explored. Finally, the movement of the visitors' and interests from the tourism strategic area to the border area was also explored which aimed to measure how much and how interesting the tourism attractions or appeals in the border area and the neighbouring country are according to the visitors. 


\section{Concept and theoretical framework}

\section{Tourism strategic area}

According to "dictionary" definition, strategic is defined as helping to achieve a plan or as object or location with an advantage. If we explore further, according to Indonesian Spatial Plan (2008), strategic area is an area with the priority for spatial arrangement in consideration to its significant influence on the matters, such as national sovereignty, and state defence and security, economy, social, culture, and environment. Furthermore, under National Tourism Development Master Plan (2011), strategic (in tourism) area is also introduced as an area which has a function and potential to develop the tourism sector and has significant influence on many aspects, such as economic, social, culture, empowerment of natural resources, as well as defence and security. Adopting from several authors, Muazir and Hsieh (2014) listed several understandings about strategic area which can be defined as an important location, target of cooperation, prestigious place, rich and important place, and selective and oriented place. Recently there are 88 tourism strategic areas in Indonesia.

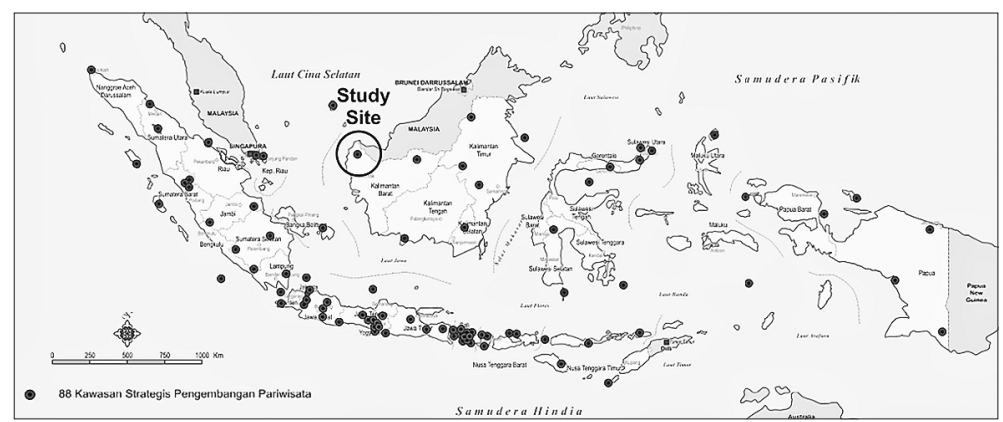

Figure 1. Tourism Strategic Areas in Indonesia and Study Site

Source: Government Regulation No. 50 (2011)

\section{Tourism market and visitor movement}

Tourism market and movement can be one of the methods to explore tourism activities. Movement patterns represent the sequence of movements by tourist/visitors from one-attraction to another (Xia et al. 2010), while market represents people who might to come. The importance of these two approaches is to understand tourist mobility that influences by their behaviour and how to accommodate it (Mckercher \& Lau, 2008). Tourism can be defined as the processes, activities, and outcomes arising from the relationships and the interactions among visitors, suppliers, host government, host communities, and surrounding environment that are involved in the attracting and hosting the visitors (Goeldner \& Ritchie, 2012). Meanwhile, market can be defined as the people who might want to buy something, or a part of the world where something is sold. From both definitions, it can be assumed that tourism market is the people who might be attracted by the attraction provided by the hosts. In tourism studies, the core questions are what makes visitors travel and what they enjoy (Silkes, 2012). Understanding the factors, such as socio-demographics, destination familiarity, motivation, and experience would help to identify the target markets. Besides, market sophistication has many specific and varied needs that can often only be acoomodated by a variety of destinations (Highet \& Johnson, 1984). In the future, there will be 
many direct and indirect influences on the visitors to decide their trips, not just beach and events, but also novelty seeking (Yeoman, 2009; Chang et al., 2007). In the "classic" work, tourism markets examined the visitors' arrivals, tourism receipts, opportunities, and constraints (Buckley \& Wit, 1987). Poon (in Perez \& Sampol, 20oo) argued that the tourism market had been segmented along demographic, socio-economic, and physiographic characteristics, including motivation, hobbies, opinions, and more. Kim et al. (2008) also mentioned that visitors' motivation and segementation could be based on demographic characteristics, such as sex, marriage, age, accompanying person, information, location, income, education level, and occupation.

Along with the information seeking about tourism market, one of the popular methods is by segmenting the market. Referring to Kim et al. (2010), as he cited from several authors, market segmentation had been commonly used to develop the understanding of the distinct characteristics of visitor segments. Several variables can be developed, such as demographics, socio-economics (occupation, income), geography, psychographics (motivation, interest), and behaviour (frequency of trips, activities). Besides, other variables such as the number of visitor arrivals, receipts, expenditure, market share to attraction, purpose of visit, source, most popular destination, norms and values, personality, and lifestyle can also be considered (Wade et al., 2001; Jie, 2001; Gonzalez \& Bello, 2002). According to Armstrong \& Kotler (2005), market segmentation is an activity to divide a market into distinct groups with distinct needs, characteristics, or bahavior who might require seperates products. Effective segmentation will also help to optimize the marketing activities as well as profitability (Richardson in McKercher, 2002). Market segmentation is considered as one of the most important strategic concepts to understand specific consuming characteristics. Good market segment consists of consumers with homogeneous needs and attitudes (Chen et al., 2010). Market segmenting makes use of different people who have different needs. The segmetation leads to a typology in which the grouping criteria are known in advance, such as sex, income, etc. (Dolnicar, 2002).

Tourism movement can be related with the concept of tours/trips inside the geographic element. According to Leiper (1979), tourist make temporary departure from the residance and become domicled in new lcoations, where spatially involves three elements, such as origin, destination, and transit. Continued by Masiero \& Zoltan (2013); as they cited from Burton, tourist movement are motivated and concentrated by the availability of attractions and activities at the destination. From the movement information, the dominant location can be founded. The dominant movement patterns are the sequences or patterns that are used by tourist most frequently, which can provide information abour popular sites (Xia et at., 2010). Oppermann (1992) said that there are two components of (international) movement, which are movement between different locations and the stay of tourist at these locations. As cited by Bowden (2013) from Pearce's, tourist flow are a three-elements, which are origin-linkage-destination and takes into account three aspects of study, which are port of entry and departure, places visited and routes followed. One of the method to explore visitor movement is by knowing their network structure. According to Hwang et al. (2006), the concept of visiting several destinations during trip can be explored by trip patterns as network structures. They introduce centrality/centralization: betweenness centrality, closeness centrality, connectedness and cohesion, structure, and direction. The benefits from movement information are to understand visitor behavior for effective tourism management (Orellana et al., 2012), to develop attraction planning, development of accomodation nodes and transportation links (Smallwood et al., 2012), to develop scenarios and visualisation of directional travel flow (Holyoak \& Carson, 2009), and overall, by understanding the movement within destination is the central understanding about how tourism works at the destination level (McKercher \& Lau, 2008) 


\section{Methodology}

To explore tourism market characteristics, we performed survey method by exploring several basic visitors' information, such as demographics, socio-economics, geography, psychographics, and behaviour. In collecting the primary data, survey method was used by distributing the questionnaires. Based on the number of visitors (tourists) who came to Sambas, we distributed 353 question naires consisting of two parts of questions. The first part of question naires derived from the general questions about common visitor characteristic variables, such as demographics, socio-economics, geography, psychographics, and behaviour. The second part of the questionnaires led the respondents to the questions about their experiences and expectations on the condition of tourism attractions in Sambas city. In addition, the movement of the visitors' travel experiences were also explored in part two by asking other attractions that they might want to visit or had visited based on their experiences in travelling to border area (inside Indonesia) or the neighbouring country. The emphasis of the above issues was "executed" through "geographical" concept approach by showing the "visitor traffic" from their origins, visited attractions, and experiences in visiting the border area or the neighbouring country. In addition to the primary data, we also conducted an interview with the local government as well as collected the documents as a cross validation for each data collected. The results from the questionnaires were compiled then translated using statistical software to be able to measure the trend frequency and distribution.

Adopted from previous part, tourism movement can be described where tourist move from their origin to destination and between destinations. To explored these trends, one of the method is by analyzing its network structure. Accordingly, we performed a network analysis using NodeXL (Smith et al., 2010) to investigate the relation or connection among the visitors' origins, visited tourism attractions, and other trips at the same time. Besides, the visitors' origins, experiences in going to the border area were also explored to understand their characteristics. The final part of this paper is a discussion on the findings in relation to the theoretical framework which is also a reflection of the writers opinions as well as the implications from findings.

This study was conducted in a tourism strategic area in Sambas district (as the capital city of the regency) centred at Sambas palace, central mosque, tombs, waterfront area, and several locations outside Sambas city, such as Sebedang Lake. All of the sites were renowned as Sambas' tourism attractions. The distribution of questionnaires was carried out in December 2014. Subsequently, the data compilation, processing, and analysis were finished afterwards up to year of 2015

\section{Case study area}

As one of the national tourism strategic areas, Sambas regency is located in the northern part of West Kalimantan with a total area of $6,395.70 \mathrm{sq}$. km, or approximately $4.36 \%$ of the total area of West Kalimantan (146,807 sq. km). Sambas regency is divided into 19 districts and 183 villages (Central Bureau of Statistic, 2014). The northern and eastern parts of Sambas are facing Sarawak-Malaysia. As one of the national strategic tourism areas, referring to the National Tourism Development Plan, Sambas regency development (strategic) area and potentials are divided into several districts; those are Sambas, Teluk Keramat, Jawai, Pemangkat, Selakau, and Tebas. Besides, being the tourism strategic area, as one of the border regencies in Indonesia, Sambas regency also has national strategic areas in terms of national spatial plan. Under 


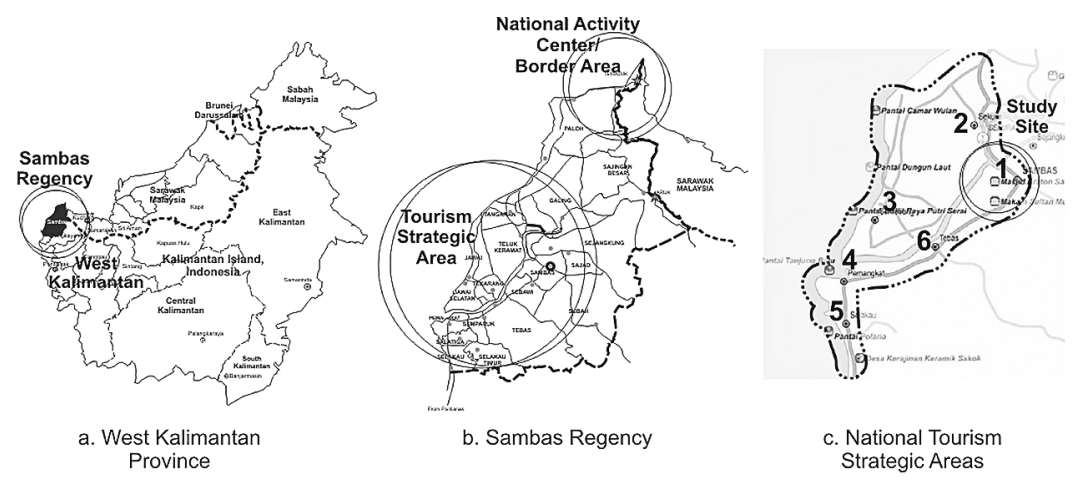

Figure 2. Tourism Strategic Areas in Sambas and National Strategic Activity Center Source: Draft of Spatial Plan (2012-2032), Government Regulation No. 50 (2011)

the national spatial structure by considering its location and influence, Paloh-Aruk area was designated as the national strategic activity centre which serves as an urban centre that encourages the development in border areas. This urban centre is determined based on several criteria, such as cross-border checkpoint, major transportation node, and centre to encourage the regional economic growth.

As one of the tourism strategic areas in Sambas regency, Sambas district is renowned for its "heritage" collections, such as palace, mosques, several tombs, and the river ambience (waterfront) that stretches along the city. The detailed description of Sambas district is described as follows in Table 1.

Table 1. Sambas District Profile

\begin{tabular}{|c|l|l|}
\hline № & \multicolumn{1}{|c|}{ Profile } & \multicolumn{1}{c|}{ Amount/Description } \\
\hline 1 & Area Cover & $246.66 \mathrm{sq} . \mathrm{km}$ \\
\hline 2 & Number of Villages & 18 \\
\hline 3 & Number of Population & 46,589 \\
\hline 4 & Population Density & $189 / \mathrm{sq} . \mathrm{km}$ \\
\hline 5 & Number of Schools & Elementary: 32, Junior High School: 10, Senior High School: 10 \\
\hline 6 & Number of Health Facilities & Hospital: 2, Health center: 3 , Village childbirth center: 16 \\
\hline 7 & Number of Nurses & 30 \\
\hline 8 & Number of Doctors & 21 \\
\hline 9 & Main Tourism Potential & Historical building, river view, tombs, art and craft \\
\hline 10 & Distance to Border area & $90 / 92 \mathrm{~km}$ \\
\hline 11 & Distance to Province Capital City & $225 \mathrm{~km}$ \\
\hline
\end{tabular}

Source: Sambas' Central Bureau of Statistic, 2015

Sambas tourism strategic areas, as mentioned above, have several areas (in scale of districts) which are included as strategic areas. With the assignment of Sambas regency as a tourism strategic area, its several common and specific potentials and tourism strategic areas can be identified as follows in Table 2 .

With its geographical location bordering with the neighbouring countries, Sarawak-Malaysia, Sambas regency with its strategic region would have benefit from a nearby source of inter- 
Table 2. Tourism Potential and Constraints

\begin{tabular}{|c|c|c|c|c|}
\hline № & Districts & \multicolumn{2}{|c|}{ Natural/ Historical Tourism Potential } & Cultural Tourism Potential \\
\hline 1 & Sambas & \multicolumn{2}{|l|}{ Palace, mosque, river view } & Tombs, historical buildings, arts and crafts \\
\hline 2 & Teluk Keramat & \multicolumn{2}{|l|}{ Plantation } & - \\
\hline 3 & Jawai & \multicolumn{2}{|l|}{ Beach } & Historical buildings, tombs \\
\hline 4 & Pemangkat & \multicolumn{2}{|l|}{ Beach } & Tombs, historical and religion buildings, monument \\
\hline 5 & Selakau & \multicolumn{2}{|l|}{ Beach } & Tombs, religion buildings \\
\hline 6 & Tebas & \multicolumn{2}{|l|}{ Cave, river view, hill } & - \\
\hline \multicolumn{3}{|c|}{ General Tourism Potentials } & & General Tourism Constraints \\
\hline \multicolumn{3}{|c|}{$\begin{array}{l}\text { 1. Directly adjacent to the international market, as well as } \\
\text { informal relationships between residents of two countries that } \\
\text { have been formed } \\
\text { 2. The presence of accommodation and local transportation } \\
\text { 3. Variety of tourism attractions } \\
\text { 4. Access (road) has been opened } \\
\text { 5. Community awareness to tourism issues has been raised and } \\
\text { monitored by local government } \\
\text { 6. Determination as a strategic area }\end{array}$} & \multicolumn{2}{|c|}{$\begin{array}{l}\text { 1. Tourism data is not developed/recorded yet } \\
\text { 2. Limitation of basic infrastructures } \\
\text { 3. The length of the distance between attractions } \\
\text { 4. Limitation of events and promotion } \\
\text { 5. The absence of regional cooperation between countries } \\
\text { 6. The lack of tourism development budget } \\
\text { 7. The absence of tourism grand/master plan and related } \\
\text { plans }\end{array}$} \\
\hline
\end{tabular}

Source: Muazir et al., 2015

national visitors. In scale of province (West Kalimantan), it is assumed that most of the foreign visitors came from Malaysia (as recorded from Entikong immigration, 2013), with 24,856 visitors (out of 30,687). Besides, nationally, the number of the visitors from Malaysia to Indonesia was also recorded as the largest after Singapore with 1,430,989 visitors. On the other hand, the same case also happened in Malaysia where the number of Indonesian visitors was also recorded as the second largest after Singapore, amounting around 2,827,533 visitors coming to Malaysia in 2014. However, there was a difference in the number of visitors coming. Looking at a regional scale, one of the cross-border checkpoints between Sarawak and Sambas located in Aruk (Sambas) - Biawak (Sarawak, Malaysia), as recorded from the Ministry of Tourism Sarawak (2013), had 22,809 foreign visitors (out of 2,664,682 foreign visitors to Sarawak). It is assumed that only from one cross-border checkpoint, Sarawak succeeded in attracting almost the same number of visitors as the whole number of visitors coming to West Kalimantan province as ever recorded. If it is viewed from the domestic perspective, there is only one main access (road) connecting Sambas to other cities/regencies in West Kalimantan. This road also connects Sambas to the province capital city, Pontianak, with its international airport (around $225 \mathrm{~km}$ ). In other words, for domestic/local visitors, Sambas can be accessed easily, although it takes 5-6 hours driving on more than 200 kilometres.

\section{Results}

\section{Tourism market characteristic and expectation}

Regardless of the existing market conditions, this study focuses more on the visitors' characteristics at the existing attractions without stressing on any principle differences between the visitors' origins (either international or domestic). From the results of the survey conducted, we found several important characteristics of the visitors to Sambas, as follows in Table 3 . 
Table 3. Tourism Market Characteristics

\begin{tabular}{|c|c|c|c|c|c|}
\hline Variables & Category & $\%$ & Variables & Category & $\%$ \\
\hline \multirow[t]{3}{*}{ Sex } & Female & 50.7 & \multirow[t]{5}{*}{ Ethnic } & Malay & 72.5 \\
\hline & Male & 47.6 & & Javanese & 17 \\
\hline & No answer & 1.7 & & Dayak & 2.5 \\
\hline \multirow[t]{6}{*}{ Religion } & Islam & 89.8 & & Chinese & 1.7 \\
\hline & No answer & 6.2 & & Sudanese & 1.1 \\
\hline & Catholic & 2.0 & \multirow[t]{6}{*}{ Travel reason } & History & 39.1 \\
\hline & Buddha & 0.8 & & Knowledge & 17.6 \\
\hline & Protestant & 0.0 & & Recreation & 14.2 \\
\hline & Other & 0.3 & & Leisure & 13.6 \\
\hline \multirow[t]{5}{*}{ Age } & Below 17 & 14.2 & & Family trip & 5.4 \\
\hline & $18-30$ & 54 & & Scenery & 3.1 \\
\hline & $31-40$ & 12.3 & \multirow[t]{5}{*}{ Main activity } & Sightseeing & 47.6 \\
\hline & $41-50$ & 9.9 & & Sightseeing and leisure & 8.2 \\
\hline & More than 51 & 9.6 & & Leisure & 13 \\
\hline \multirow[t]{4}{*}{ Origin } & Sambas & 39.7 & & Eating and leisure & 3.4 \\
\hline & West Kalimantan & 51 & & Taking picture & 2.5 \\
\hline & Outside West Kalimantan & 7.9 & \multirow{6}{*}{$\begin{array}{l}\text { Travel } \\
\text { Frequencies }\end{array}$} & Once a year & 31.2 \\
\hline & Outside Indonesia & 0.6 & & Once a month & 28.6 \\
\hline \multirow[t]{6}{*}{ Education } & Elementary & 8.2 & & Event & 17.8 \\
\hline & Junior High School & 10.5 & & Twice a year & 7.6 \\
\hline & Senior High School & 43.3 & & Once a week & 11.6 \\
\hline & Vocational & 6.5 & & Four times a year & 1.1 \\
\hline & Bachelor & 20.4 & \multirow[t]{4}{*}{ Transportation } & Motorcycle & 49.6 \\
\hline & Master & 4.5 & & Car & 39.7 \\
\hline \multirow[t]{4}{*}{ Occupation } & Private Sector & 32.6 & & Rental car & 9.1 \\
\hline & Student & 29.4 & & Bus & 0.8 \\
\hline & Government & 17 & \multirow{4}{*}{$\begin{array}{l}\text { Internet user } \\
\text { (searching } \\
\text { travel } \\
\text { information) }\end{array}$} & Active & 51.8 \\
\hline & Not Working & 17.2 & & Not active & 43.3 \\
\hline \multirow{5}{*}{$\begin{array}{l}\text { Income } \\
\text { (IDR) }\end{array}$} & $0-1,000,000$ & 15 & & Sometimes & 3.1 \\
\hline & $1,000,001-2,000,000$ & 13.3 & & Rarely & 1.7 \\
\hline & $2,000,001-3,000,000$ & 10.8 & \multirow{6}{*}{$\begin{array}{l}\text { Expenditure } \\
\text { Allocation }\end{array}$} & Food & 26.2 \\
\hline & $3,000,001-5,000,000$ & 8.2 & & Food, Transportation & 13.3 \\
\hline & More than $5,000,000$ & 4.5 & & Transportation & 14.1 \\
\hline \multirow{5}{*}{$\begin{array}{l}\text { Expenditure } \\
\text { (IDR) }\end{array}$} & $0-100,000$ & 42.5 & & Food, Transportation, Shopping & 2.5 \\
\hline & $100,001-500,000$ & 21 & & Food, Entrance Fee & 2.5 \\
\hline & $500,001-1,000,000$ & 11.6 & & Accommodation & 1.7 \\
\hline & $1,000,001-5,000,000$ & 8.5 & & & \\
\hline & $5,000,001-10,000,000$ & 2 & & & \\
\hline \multirow[t]{3}{*}{ Status } & Single & 55.5 & & & \\
\hline & Marriage & 42 & & & \\
\hline & Other & 2.5 & & & \\
\hline
\end{tabular}


In addition to the basic characteristics listed above, we also explored the visitors' "opinions" or responses related to the existing facilities and services at the destination area. In exploring the visitors' responses, we asked them about the conditions of the facilities, such as road/ access condition, electricity, communication, security, people hospitality, etc. We also asked them about which facilities supported their tourism activities and which one did not support their activities. Besides, an option was provided for the visitors to express their preferences on the "optimum" facilities that concluded by questioning their expectations regarding the provision of the "alternative facilities" needed. The summary of the findings is described in Table 4.

Table 4. Visitor Opinion and Expectation

\begin{tabular}{|c|c|c|c|c|c|}
\hline Variables & Category & $\%$ & Variables & Category & $\%$ \\
\hline \multirow[t]{2}{*}{ Road/ Access } & Support & 58.1 & \multirow[t]{11}{*}{ Good Facilities } & People hospitality & 41.9 \\
\hline & Not support & 39.7 & & Road/access & 14.2 \\
\hline \multirow[t]{2}{*}{ Electricity } & Support & 71.1 & & Fresh water & 9.6 \\
\hline & Not support & 22.7 & & Security & 6.8 \\
\hline \multirow[t]{2}{*}{ Fresh water } & Support & 64.6 & & Electricity & 4.8 \\
\hline & Not support & 31.7 & & Environment & 4.8 \\
\hline \multirow[t]{2}{*}{ Trash bin } & Support & 52.1 & & Telecommunication & 2.5 \\
\hline & Not support & 43.6 & & Trash bin & 2.3 \\
\hline \multirow[t]{2}{*}{ Telecommunication } & Support & 70 & & Shopping & 1.7 \\
\hline & Not support & 27.5 & & Cleanness & 1.4 \\
\hline \multirow[t]{2}{*}{ Internet access } & Support & 60.6 & & Other & \\
\hline & Not support & 35.4 & \multirow[t]{11}{*}{ Expected Facilities } & Garden & 9.9 \\
\hline \multirow[t]{2}{*}{ Entertainment } & Support & 38.5 & & Free internet access & 7.1 \\
\hline & Not support & 57.8 & & Relaxing places & 6.5 \\
\hline \multirow[t]{2}{*}{ Shopping } & Support & 47 & & Playground & 4.8 \\
\hline & Not support & 49 & & Entertainment & 3.7 \\
\hline \multirow[t]{2}{*}{ Security } & Support & 85.3 & & Souvenir & 2.8 \\
\hline & Not support & 11 & & Better environment & 2.5 \\
\hline \multirow[t]{2}{*}{ Hospitality } & Support & 90.1 & & Shelter & 2.5 \\
\hline & Not support & 7.1 & & Better land use & 2.3 \\
\hline \multirow[t]{12}{*}{ Bad Facilities } & Road/access & 29.7 & & Toilet & 2.3 \\
\hline & Entertainment & 26.9 & & Other & \\
\hline & Trash bin & 5.1 & \multirow{10}{*}{$\begin{array}{l}\text { Other Interesting } \\
\text { Places }\end{array}$} & Singkawang beach & 17.3 \\
\hline & Fresh water & 4.8 & & Temajuk village & 6.2 \\
\hline & Telecommunication & 3.1 & & Singkawang city & 5.7 \\
\hline & Internet access & 2.8 & & Sebedang lake & 4.2 \\
\hline & Environment & 1.7 & & Pasir Panjang beach & 3.7 \\
\hline & Cleanness & 1.4 & & Bukit Jamur & 2.5 \\
\hline & Shopping & 1.4 & & Sebedang lake, Singkawang beach & 1.7 \\
\hline & Information & 1.1 & & Temajuk beach & 1.4 \\
\hline & Other & & & Singkawang, Mempawah & 1.1 \\
\hline & & & & Other & \\
\hline
\end{tabular}




\section{Visitors' movement: origin, destination, and transit}

The model developed here was gained by exploring the locations or point by point of trips performed by the visitors. The model sorting was started from the visitors' origins, places visited, and the possibility of other places to visit. In addition, the visitors' experiences in visiting the tourism attractions in the border area or the neighbouring country were also explored. To understand the trip trends or the movement from one place to another, several measurement techniques was performed in terms of network analysis. The measurements were ranging as follows: (1) "in-degree" to determine the amount (trend) of the tourism attractions already chosen as well as the trip experiences to border area/neighbouring country; (2) "out-degree" to find out the distribution of the visitors' origins; and (3) the combination of "in/out degree" to discover the diffusion of the visitors from their current attractions to other attractions in the same trips/activities. In addition to using the "degree" measurement, the existence of the important locations or places was also considered. The important location here was defined as one location that could be a "bridge" to another location or had a close relationship to other locations. This measurement was performed by measuring the network centrality using betweenness, closeness, and eigenvector formulas. Based on the calculation was found the "relationship graph" as follows:

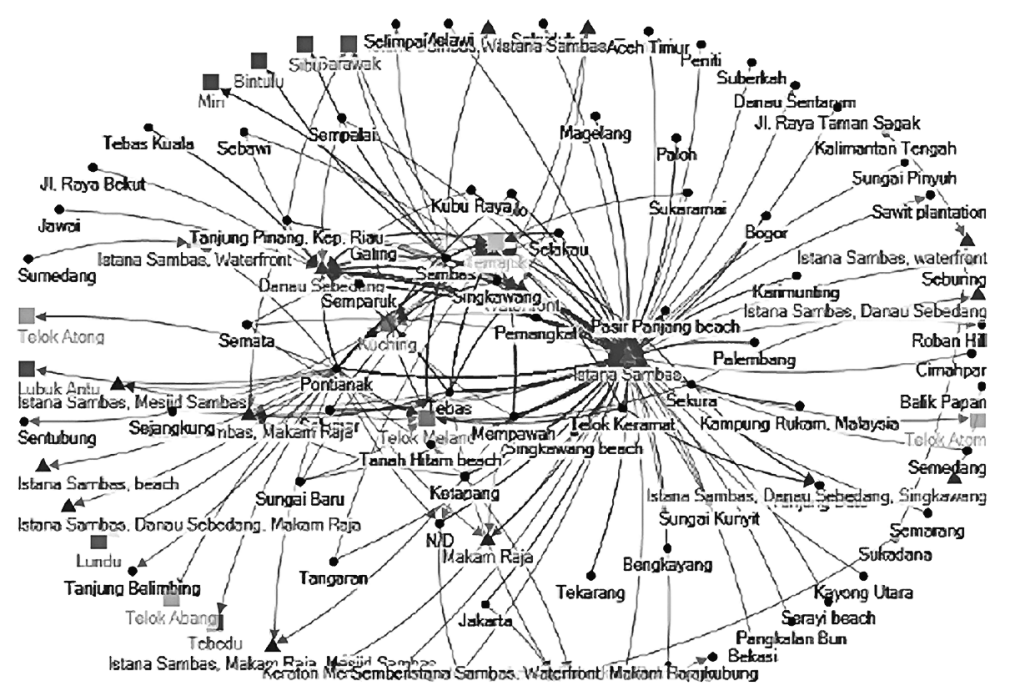

Figure 3. Market Network Graph

Source: Analysis (2015)

If we translate the graph into several measurements and calculate it using NodeXL, we can consider several values from the result.

In terms of the visitors' origins ("out-degree"), Pontianak as the provincial capital city became the main source of the visitors who came to the tourism attractions in Sambas although the distance between these two cities was far. Moreover, the residents of Sambas (including Tebas, Sekura, Telok Melano, and Selakau) and other cities passed through along the accessing roadway, such as Singkawang and Mempawah also contributed the most visitors. Interestingly, the inhabitants of one of the regencies located far from Sambas, namely Ketapang regency, were also interested in visiting the tourism attractions in Sambas. From the sur- 
Table 5. Location Degree and Centrality (the highest)

\begin{tabular}{|c|c|c|c|c|c|c|c|c|c|c|}
\hline \multirow{2}{*}{$\frac{\text { № }}{1}$} & \multicolumn{2}{|c|}{ InDegree } & \multicolumn{2}{|c|}{ OutDegree } & \multicolumn{2}{|c|}{ Betweenness } & \multicolumn{2}{|c|}{ Closeness } & \multicolumn{2}{|c|}{ Eigenvector } \\
\hline & $\begin{array}{l}\text { Sambas } \\
\text { Palace }\end{array}$ & 53 & Pontianak & 21 & $\begin{array}{l}\text { Sambas } \\
\text { Palace }\end{array}$ & 7188.7 & Balikpapan & 1 & $\begin{array}{l}\text { Sambas } \\
\text { Palace }\end{array}$ & 0.082 \\
\hline 2 & $\begin{array}{l}\text { Sebedang } \\
\text { Lake }\end{array}$ & 16 & Sambas & 13 & Pontianak & 2151.6 & $\begin{array}{l}\text { Sambas } \\
\text { Palace, } \\
\text { Sebedang } \\
\text { Lake, } \\
\text { Singkawang }\end{array}$ & 1 & Temajuk & 0.036 \\
\hline 3 & Temajuk & 16 & $\begin{array}{l}\text { Sambas } \\
\text { Palace }\end{array}$ & 12 & Sambas & 1167.6 & $\begin{array}{l}\text { Sambas } \\
\text { Palace }\end{array}$ & 0.007 & $\begin{array}{l}\text { Sebedang } \\
\text { Lake }\end{array}$ & 0.032 \\
\hline 4 & $\begin{array}{l}\text { Telok } \\
\text { Melano }\end{array}$ & 10 & Tebas & 8 & $\begin{array}{l}\text { Sebedang } \\
\text { Lake }\end{array}$ & 983.2 & $\begin{array}{l}\text { Sebedang } \\
\text { Lake }\end{array}$ & 0.005 & Pontianak & 0.030 \\
\hline 5 & Kuching & 8 & Singkawang & 8 & Tebas & 654.6 & Temajuk & 0.005 & Sambas & 0.025 \\
\hline 6 & Waterfront & 7 & Mempawah & 6 & $\begin{array}{l}\text { Sambas } \\
\text { Palace } \\
\text { complex }\end{array}$ & 578.2 & Pontianak & 0.005 & Tebas & 0.022 \\
\hline 7 & $\begin{array}{l}\text { Sambas } \\
\text { Palace, } \\
\text { Waterfront }\end{array}$ & 4 & Sekura & 6 & Sekura & 494.3 & Sambas & 0.005 & Singkawang & 0.022 \\
\hline 8 & $\begin{array}{l}\text { Sambas } \\
\text { Palace, } \\
\text { Makam }\end{array}$ & 4 & Ketapang & 5 & Temajuk & 427.5 & Waterfront & 0.005 & Waterfront & 0.020 \\
\hline 9 & Makam Raja & 3 & $\begin{array}{l}\text { Telok } \\
\text { Keramat }\end{array}$ & 4 & Sukadana & 388 & Tebas & 0.005 & Mempawah & 0.019 \\
\hline 10 & $\begin{array}{l}\text { Sambas } \\
\text { Palace } \\
\text { complex }\end{array}$ & 3 & Selakau & 4 & Ketapang & 275.7 & Tombs & 0.005 & Galing & 0.018 \\
\hline
\end{tabular}

Source: Analysis, 2015

vey, there were only two Malaysian visitors who visited Sambas Palace. They were interested in the palace because they wanted to see the historical building and the surrounding areas. Regarding the most visited attractions ("in-degree"), Sambas Palace was still the main tourism attraction for visitors followed by Sebedang Lake, waterfront area, King's tombs, which, in fact, these location (except Sebedang Lake) were interconnected to each other and could be accessed by walking or using vehicle. For further travel location (attraction) options, many visitors were interested to continue their trips starting from Sambas Palace to Sebedang Lake and other attractions near Sambas Palace (waterfront area and tombs). This condition showed that Sambas Palace was one of the important attractions (locations) in terms of transit where the activities were diffused.

Related to the visitors' interests in the border area or neighbouring country (Sarawak, Malaysia), Temajuk-Paloh was still attractive with its beach and turtle breeding. From "in/ out degree" measurement, Temajuk (in Sambas), as well as Telok Melano and Kuching (in Sarawak) were popular locations in the border area and neighbouring country. For the frequency, $16.4 \%$ of the total visitors surveyed had visited Temajuk, and $19.3 \%$ of them visited Sarawak, Malaysia. From the results, it can be seen that the neighbouring country was more "attractive" for the visitors than the State's border area. Judging from the origins of the visitors, Pontianak and Sambas were the sources of most visitors to the Temajuk. Likewise, many visitors who visited Sarawak, Malaysia came from Pontianak and Sambas. 
Furthermore, to explore which location was important as its relations and "diffusion", we considered its centrality. Adopted from Wasserman and Faust (1994), betweenness is the one in the middle, the one between the others, and become a "bridge" between others. Also, closeness centrality reflects how close the actors are to each other, which means that an actor is central if it quickly interacts with all others. The third approach is eigenvector which is an effort to find the most central actors in terms of the overall network structure (Hanneman and Riddle, 2005). As the "special" locations which were capable at linking among locations (betweenness), Sambas Palace, Pontianak, and Sebedang Lake seemed to be the important locations in the network. Sambas Palace and Sebedang Lake were two attractions which became the main destinations as well as the transit areas to the next destinations (diffusion). On the contrary, Pontianak and Sambas were two locations that connected other locations to the tourism attractions in Sambas. If viewed from the level of the closeness, Sambas Palace, Sebedang Lake, and Temajuk were the locations that were close to other locations and could quickly interacted to other locations. Balikpapan with its "out-degree" had a high value of closeness because it only interacted directly with one of each location but not with all locations inside the network. Therefore, it was not accounted for as the important location in the "whole network", but it was in terms of only local context. To close our exploration in "centrality," in the scale of eigenvector, it was assumed that Sambas Palace, Temajuk, Sebedang Lake, Pontianak, etc. were still the most central locations in the whole network. Interestingly, Temajuk, which is a border area, was also included as the most central location when compared with the neighbouring country.

\section{Discussion and closing statement}

From the several findings above, some important things to consider in developing the tourism area (by looking at its visitors' characteristics) in Sambas are:

1. The main visitors to Sambas were domestic visitors who came from Pontianak, Sambas, Singkawang, Mempawah, and other areas that were connected by the main road along the coastal area. Most of the visitors had an interest or curiosity in historical building and recreational activities. Hence, their activities were mostly related with sightseeing, leisure, and culinary activities.

2. The tourism management and stakeholders need to pay attention on other visitors' characteristics in order to provide an appropriate "place" and service in accordance with the "segmentation." These characteristics range from occupation, age, level of education, expenditure and allocation, income level, vehicle facilities, and the provision of web-based information.

3. The visitors' expectations and interests are also worthwhile to consider the management of the existing tourism attractions. The visitors' expectations, interests, and imaginations about visiting one place (e.g. beach, village, city life, etc.) need to be considered to assess the quality and upgrade the facilities. Besides, the assessment on other attractions outside Sambas needs to be developed in order to raise the benefit from the existing attractions and their future development.

4. Related to the locations that were considered to be important or "central" inside the "constellation" (network) of the origins and attractions, Pontianak and other connected cities/regencies along the "north coast" became the important locations in contributing visitors to Sambas. Sambas Palace and Sebedang Lake acted as the central points in the network, either as the main attractions or as the starting points to the next trips. The 
connecting trips of the visitors still circled around Sambas (Sambas Palace, Sebedang Lake, waterfront, and King's tombs). Interestingly, the border area in Temajuk and the neighbouring country (Sarawak, Malaysia) also became the major attractions and places where visitors "desired" to visit. In addition, inside the network, Temajuk became the central point (important place) after Sambas Palace.

Related with several important facts mentioned above, the tourism development in Sambas can be arranged by considering the tourism market and the attempts to respond it. The tourism attractions that exist can be evaluated and adjusted to the market expectations. Moreover, other market variables are also needed to consider. To be more detailed, knowing and understanding the tourism market are useful to set the attractions to produce appealing needs for each segment (McKercher et al., 2002). Then, tourism segmentation (by selective targeting) can also help to construct the region appeals (Pearce, 1997). To meet the needs of the market, at least basic infrastructure is also worth to consider (Wade et al., 2001). Basic infrastructures are useful to connect the attractions or areas with the facilities that can provide pleasure and comfort for the visitors. After the market and attraction evaluation (matching) is conducted, the development prioritisation and differentiation of attraction may be delivered (Yeoman, et al., 2009). The prioritisation might focus on each character or visitor segment that exists. It can be geographical (so the access should be upgraded), or based on the visitors' expectations (so new attractions are needed), or according to other considerations. After the "communication" takes place between the market and products (attractions), the market and its prospect needed to be picked up by packaging promotion efforts and awareness campaigns for the attractions and existing tourism products (Perez et al., 2005). The suitability and market changes should be continuously monitored (Koc, 2006) in order to keep tourism products and service adapting.

In terms of tourism attractions, the products or specific attractions (different from other competitors) are maintained and directed to create new segments. According to the BaudBovy \& Lawson (2002), the development of tourism products can be initiated by specific product. The product itself can be located in the centre and spread over a region or blended with several interests. Related to the central location and diffusion, if each point is put inside a map, it will describe some important points in form of origins, attractions visited, and the next movements to the other attractions as well as the border areas. From these important locations, the tourism development in Sambas can be started by giving attention to the domestic and inter-

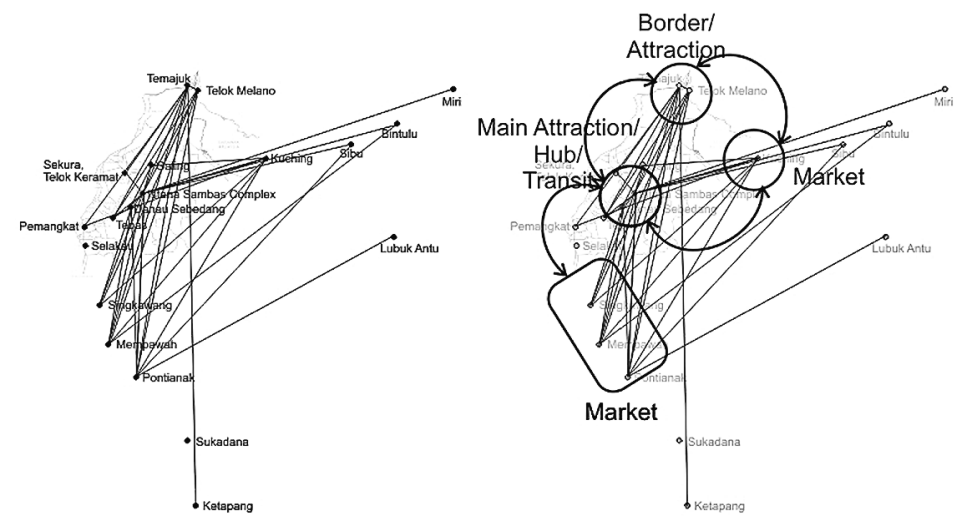

Figure 4. Original Network and Locations (left) and Recommendation (right)

Source: Analysis (2015) 
national markets. The visitors from the province capital city (Pontianak) and in line with it can be a major concern in how to attract and satisfy them. In addition, in terms of its closeness to the international market, Sarawak-Malaysia, Sambas regency should be also strengthened by providing a good access and attraction options. The tourism attractions in Sambas can serve as a central or connector to other attractions, both within the region and in international market. As becoming the centre (hub), transit, and connector, Sambas tourism strategic areas can contribute to the border area (national strategic activity centre) by distributing trips. Likewise, the border area may become the main entrance for international visitors to Sambas. From both interactions, the development pulse from and to each area is expected to co-exist.

As a closing statement, it needs to be emphasised that the main tourism market in tourism strategic areas was still dominated by domestic market. These visitors did not only visit the tourism attractions in Sambas, but also reached the border area and neighbouring country. This market niche can be "exploited" by Sambas by rearranging their attraction hierarchy and by placing the attractions around Sambas Palace as the centre of activities which later can be diffused to other locations. Related with the border area, there are two functions that are born, as a part of a journey from the central and as the main entrance. The consequence of these two functions is to provide a good access and appropriate attractions.

\section{References}

Andreu, L., Kozak, M., Avci, N., Cifter, N. 2005. Market Segmentation by Motivations to Travel. Journal of Travel E Tourism Marketing, 19(1), 1-14.

Armstrong, G., Kotler, P. 2005. Marketing; An Introduction. Pearson Edition, Inc., New Jersey. Baud-Bovy, M., Lawson, F. 2002. Tourism and Recreation Handbook of Planning and Design. Architectural Press, Oxford.

Bowden, J. 2003. A Cross-National Analysis of International Tourist Flow in China. Tourism Geographies: An International Journal of Tourism Space, Place, and Environment, 5(3), 257279.

Buckley, P, J., Witt, S, F. 1987. The International Tourism Market in Eastern Europe. The Service Industries Journal, 7(1), 91-104.

Cambridge Dictionary Online. 2015. Words Definition. URL: http://dictionary.cambridge.org/ (Accessed on May, 2015)

Chang, J., Min, J, C. H., Lin, Y-H, P., Chiang, C, H. 2007. Profiling Japanese Tourists Visiting Night Markets in Taiwan. Journal of Quality Assurance in Hospitality \& Tourism, 8(2), 25-44.

Chen, J, S., Chang, L-L, Cheng, J-S. 2010. Exploring Market Segments of Farm Tourism in Taiwan. Journal of Hospitality Marketing \& Management, 19(4), 309-325.

Diaz-Perez, F.M., Bethencourt-Cejas, M., Alvarez-Gonzales. 2005. The Segmentation of Canary Island Tourism Markets by Expenditure Implications for Tourism Policy. Tourism Management 26, 961-964.

Dolnicar, S. 2002. A Review of Data-Driven Market Segmentation in Tourism. Journal of Travel E Tourism Marketing, 12(1), 1-22.

Goeldner, C, R., Ritchie, J. R. 2012. Tourism: Principles, Practices, Philosophies. Twelfth Edition. John Wiley \& Sons, New Jersey.

Gonzalez, A, M., Bello, L. 2002. The Construct Lifestyle in Market Segmentation. European Journal of Marketing, 36(1-2), 51-85. 
Hanneman, R., Riddle, M. 2005. Introduction to Social Network Methods. On line Textbook of Social Network Analysis. URL: http://faculty.ucr.edu/ hanneman/ (Accessed on May, 2015).

Highet, B, P., Johnson, W, H. 1984. Harlem - Tourism Market Assessment and Potential. Tourism Management, June 1984.

Holyoak, N., Carson, D. 2009. Modelling Self-Drive Tourist Pattern in Desert Australia. The 32 Australasian Transport Researh Forum - ATRF. Auckland, New Zealand.

Hwang, Y-H., Gretsel, U., Fesenmaier, D, R. 2006. Multicity Trip Patterns, Tourist to The United States. Annals of Tourism Research, 33, 1057-1078.

Jie, D, Q, D. 2001. A Study of Mainland China Outbound Tourism Markets. Tourism Review, 56(1-2), 44-47.

Kim, A, K., Keuning, J., Robertson, J., Kleindorfer, S. 2010. Understanding the Birdwatching Tourism Market in Queensland, Australia. Anatolia, An International Journal of Tourism and Hospitality Research, 21(2), 227-247.

Kim, S, S., Kim, M., Park, J., Guo, Y. 2008. Cave Tourism: Tourist' Characteristics, Motivations to Visit, and the Segmentation of Their Behaviour. Asia Pacific Journal of Tourism Research, 13(3), 299-318.

Koc, E. 2005. New Product Development in the Turkish Tourism Market: The Case of Football Tourism. Journal of Sport \& Tourism, 10(03), 165-173.

Leiper, N. 1979. The Framework of Tourism: Towards a Definition of Tourism, Tourist, and the Future Tourist Industry. Annals of Tourism Research. Oct/Dec

Liu, Y-D. 2014. Image-Based Segmentation of Cultural Tourism Market: The Perceptions of Taiwan's Inbound Visitors. Asia Pacific Journal of Tourism Research, 19(8), 971-987.

Masiero, L., Zoltan, J. 2013. Tourist Intra-Destination Visits and Transport Mode: A Bivariate Probit Model. Annals of Tourism Research, 43, 529-546.

McKercher, B., Ho, P, S. Y., Cross, H, D., So-Ming, B, C. 2002. Activities-Based Segmentation of the Cultural Tourism Market. Journal of Travel E Tourism Marketing, 12(1), 23-46.

McKercher, B., Lau, G. 2008. Movement Patterns of Tourist within a Destination. Tourism Geographies: An International Journal of Tourism Space, Place, and Environment, 10(3), 355-374.

Ministry of Tourism Sarawak. 2013. Sarawak Tourism Quick Facts 2013. Statistical Data

Ministry of Tourism. 2010. Ministry of Tourism Strategic Plan 2010-2014. Government Regulation.

Ministry of Tourism. 2013. Tourism Statistics. Statistical Data. URL: http://www.parekraf. go.id/asp/ringkasan.asp?c=87 (Accessed on May, 2015)

Muazir, S., Hsieh, H, C. 2015. People, Places, and Orientation: Urban System and Social Network in Lagging-Strategic Area (Borderland) in Indonesia. Paper presented at the $8^{\text {th }}$ International Conference on Planning and Design, $25^{\text {th }}-28^{\text {th }}$ May 2015.

Muazir, S., Nurhamsyah, M., Alhamdani, M, R. 2015. Designing National Tourism Strategic Area (Borderland) in West Kalimantan, Conditions, Concepts, and Development. Paper presented at National Conference: The Application of the Science and Technology $27^{\text {th }}-28^{\text {th }}$ May 2015.

Oppermann, M. 1992. Intranational Tourist Flows in Malaysia. Annals of Tourism Research, 19, 482-500.

Orellana, D., Breht, A, K., Ligtenberg, A., Wachwociz, M. 2012. Exploring Visitors Movement Patterns in Natural Recreational Areas. Tourism Management 33, 672-682. 
Pearce, D, G. 1997. Tourism Markets and Marketing in Sarawak, Malaysia. Journal of Travel E Tourism Marketing, 6(3-4), 85-201.

Perez, E, A., Sampol, C, J. 20oo. Tourist Expenditure for Mass Tourism Market. Annals of Tourism Research, 27(3), 624-637.

Sambas's Central Bureau of Statistic. 2014. Sambas's Statistical Data. Statistical Data. URL: http://sambaskab.bps.go.id/index.php?hal=publikasi (Accessed on May, 2015).

Silkes, C, A. 2012. Farmer's Markets: A Case for Culinary Tourism. Journal of Culinary Science E Technology, 10(4), 326-336.

Smallwood, C, B., Beckley, L, E., Moore, S, A. 2012. An Analysis of Visitor Movement Patterns Using Travel Networks in a Large Marine Park, North-Western Australia. Tourism Management 33, 517-528.

Smith, M., Milic-Frayling, N., Shneiderman, B., Mendes Rodrigues, E., Leskovec, J., Dunne, C., 2010. NodeXL: a free and open network overview, discovery and exploration add-in for Excel 2007/2010, URL: http://nodexl.codeplex.com/ from the Social Media Research Foundation, http://www.smrfoundation.org.

The Government of Republic of Indonesia. 2008. National Spatial Plan. Government Regulation.

The Government of Republic of Indonesia. 2011. Tourism Grand Master Plan in Indonesia 2010-2025. Government Regulation.

The Government of Sambas Regency. 2013. Draft of Spatial Plan 2012-2032.

The Tourist Development Corporation of Malaysia. 2013. Tourist Arrivals \& Receipts to Malaysia. Statistical Data. URL: http://corporate.tourism.gov.my/research.asp?page=facts_figures, (Accessed on May, 2015).

Wade, D, J., Mwasaga, B. C, Eagles, P, F. J. 2001. A History and Market Analysis of Tourism in Tanzania. Tourism Management 22, 93-101.

Wasserman, S., and Faust, K. 1994. Social Network Analysis: Methods and Applications. USA, Cambridge University Press.

West Kalimantan Central Bureau of Statistic. 2014. West Kalimantan Statistical Data. Statistical Data. URL: http://kalbar.bps.go.id/ (Accessed on May, 2015).

Wikipedia (2015) Tourism in Malaysia. URL: http://en.wikipedia.org/wiki/Tourism_in_Malaysia (Accessed on May, 2015).

Xia, J., Evans, F, H., Spilsbury, K., Ciesielski, V., Arrowsmith, C., Wright, G. 2010. Market Segments based on the Dominant Movement Patterns of Tourists. Tourism Management 31, 464-469.

Yeoman, I., Greenwood, C., McMahon-Beattie, U. 2009. The Future of Scotland's International Tourism Markets. Future 41, 387-395. 